\title{
Kandungan Logam Berat Timbal (Pb) Pada Air, Sedimen, Dan Kerang Hijau (Perna viridis) Di Perairan Trimulyo Dan Mangunharjo Semarang
}

\author{
Fita Mirawati*, Endang Supriyantini, Ria Azizah Tri Nuraini \\ Program Studi Ilmu Kelautan, Fakultas Perikanan dan Ilmu Kelautan,Universitas Diponegoro \\ Kampus Tembalang, Semarang 50275 Telp/Fax. 024-7474698 \\ Email: fita_mirawati@yahoo.co.id
}

\begin{abstract}
Abstrak
Trimulyo dan Mangunharjo merupakan salah satu kawasan pesisir Semarang yang memiliki kawasan industri disekitarnya, sehingga berpotensi menjadi sumber logam berat $\mathrm{Pb}$ yang mencemari perairan. Penelitian ini bertujuan untuk mengetahui kandungan logam berat $\mathrm{Pb}$ pada air, sedimen, dan kerang hijau ( $\mathrm{P}$. viridis) dan mengetahui batas konsumsi mingguan kerang hijau (P. viridis). Penelitian ini dilaksanakan pada bulan Januari-Maret 2016. Metode penelitian adalah metode studi kasus dan pemilihan lokasi menggunakan metode purposive sampling. Sampel diambil dengan tiga kali pengulangan. Analisa logam berat menggunakan AAS (Atomic Absorbtion Spectrophotometry), sedangkan analisa keamanan konsumsi menggunakan MTI (Maximum Tolerable Intake). Hasil kisaran kandungan logam berat $\mathrm{Pb}$ dalam air pada Perairan Trimulyo dan Mangunharjo Semarang rata-rata sebesar $<0,003 \mathrm{mg} / \mathrm{l}$. Kandungan logam berat $\mathrm{Pb}$ dalam sedimen pada Perairan Trimulyo berkisar antara $<0,030-5,96 \mathrm{mg} / \mathrm{kg}$, dan pada Perairan Mangunharjo berkisar antara <0,030-3,69 mg/l. kandungan logam berat $\mathrm{Pb}$ dalam jaringan lunak kerang hijau (Perna viridis) pada Perairan Trimulyo berkisar antara 0,26-0,32 $\mathrm{mg} / \mathrm{kg}$ dan pada Perairan Mangunharjo berkisar antara 0,19-0,39 mg/kg. Berat maksimal asupan kerang hijau (P. viridis) yang aman dikonsumsi perminggu pada Perairan Trimulyo dan Mangunharjo Semarang untuk individu dengan berat badan $60 \mathrm{~kg}$ yaitu 5,769 $\mathrm{kg} /$ minggu dan 7,895 kg/minggu. sedangkan untuk individu dengan berat badan $45 \mathrm{~kg}$ yaitu $4,327 \mathrm{~kg} / \mathrm{minggu}$ dan $5,921 \mathrm{~kg} / \mathrm{minggu}$.
\end{abstract}

Kata kunci : Logam Berat Pb, P. viridis, MTI

Abstract

Trimulyo and Mangunharjo is one of Semarang coastal area which has a surrounding industrial area, so it could potentially be a source of heavy metals $\mathrm{Pb}$ polluting waters. This study aims to determine the content of heavy metals $\mathrm{Pb}$ in water, sediments, and mussels (P. viridis) and know the limits of weekly consumption of green mussel (P. viridis). This study was conducted in January-March, 2016. The research method was the case study method and site selection using purposive sampling method. Samples were taken with three repetitions. Heavy metal analys using AAS (Atomic Absorption Spectrophotometry), while the consumption safety analysis using MTI (Maximum Tolerable Intake). Results range Pb heavy metal content in Trimulyo and Mangunharjo Waters average of $<0,003 \mathrm{mg} / \mathrm{l}$. Pb heavy metal content in the sediment at the Aquatic Trimulyo ranged from <0,030 to 5,96 mg/kg, and Mangunharjo ranged from <0,030 to 3,69 $\mathrm{mg} / \mathrm{l}$. Heavy metal Pb content in the soft tissues of green mussel (P. viridis) on Trimulyo ranged from 0,26 to 0,32 $\mathrm{mg} / \mathrm{kg}$ and the Aquatic Mangunharjo ranged from 0,19 to $0,39 \mathrm{mg} / \mathrm{kg}$. Weight maximum intake of green mussel (P. viridis) are safe to take a week at the Aquatic Trimulyo and Mangunharjo Semarang for individuals with a weight of $60 \mathrm{~kg}$ is $5,769 \mathrm{~kg} /$ week and 7,895 kg/week. while for individuals weighing $45 \mathrm{~kg}$ is 4,327 kg/week and 5,921 kg/week.

Keywords : heavy metal $P b, P$. viridis, $M T I$

\section{PENDAHULUAN}

Trimulyo dan Mangunharjo Semarang merupakan salah satu pesisir yang ada di Kota Semarang. Kedua lokasi tersebut dibangun kawasan industri yang cukup besar. Hal tersebut berpotensi terjadinya pembuangan limbah di badan sungai yang nantinya akan bermuara ke laut jawa dan menyebabkan pencemaran perairan (Palar, 1994).

Logam berat $\mathrm{Pb}$ banyak digunakan dalam industri, seperti industri produksi baterai, amunisi, pelapis kabel, pipa, pewarna dan campuran dalam

\footnotetext{
*) Corresponding author

http://ejournal.undip.ac.id/index.php/buloma

Diterima/Received :10-07-2016

buloma.undip@gmail.com

Disetujui/Accepted :22-08-2016
} 
pembuatan pelapis keramik, serta bahan bakar (Fardiaz, 2002).

Kerang hijau (P. viridis) selain bersifat fiter feeder dan sessile juga banyak ditemukan dikedua lokasi penelitian, sehingga cocok untuk dijadikan bioindikator perairan. Bahan pencemar masuk kedalam perairan melalui proses akumulasi fisik, kimia, dan biologi. Pada proses fisika-kimia logam berat terabsorbsi, terjadi pertukaran ion dan terendapkan didasar perairan. Pada proses biologi logam berat akan terserap oleh plankton, avertebrata dan ikan yang nantinya akan dikonsumsi oleh manusia (Mandelli, 1976).

Tujuan dari penelitian ini adalah untuk mengetahui kandungan logam berat Timbal $(\mathrm{Pb})$ pada air, sedimen, dan kerang hijau (P. viridis) dan tingkat pencemarannya serta mengetahui batas maksimum konsumsi mingguan kerang hijau (P. viridis) yang mengandung logam berat $\mathrm{Pb}$ di perairan Trimulyo dan Mangunharjo Semarang.

\section{MATERI DAN METODE}

Materi penelitian ini adalah sampel air, sedimen, dan kerang hijau (P. viridis) di Perairan Trimulyo dan Mangunharjo Semarang. pada saat bersamaan dilakukan pengamatan terhadap suhu, salinitas, pH,arus, kedalaman, kecerahan dan kandungan oksigen terlarut (DO) di Perairan Trimulyo dan Mangunharjo Semarang dengan 3 kali pengulangan sebagai parameter perairan.

Metode yang digunakan dalam penelitian ini adalah metode studi kasus yaitu pengujian secara rinci terhadap suatu latar, objek, atau tempat tertentu (Bogdan dan Bikien, 1982). Stasiun pengambilan sampel ditentukan berdasarkan Purposive Sampling Method, yaitu metode sampling dengan memilih sekelompok subjek berdasarkan ciri dan sifat tertentu yang sudah diketahui sebelumnya (Hadi, 1990).

Dalam penelitian ini terdapat 2 lokasi penelitian dan 3 stasiun penelitian di setiap lokasinya. Berikut penjelasan masing-masing stasiun penelitian yaitu Lokasi Trimulyo dan Lokasi Mangunharjo:

Stasiun 1 : daerah 500 meter sebelum muara sungai atau daerah pemukiman.

Stasiun 2 : muara sungai. Stasiun 3 : daerah laut. Tiga stasiun pengambilan sampel bisa dilihat pada Gambar 1.

Penelitian ini dilakukan pada bulan JanuariMaret 2016. Sampling dilakukan pada 3 titik dan 3 kali pengulangan di setiap lokasinya. Pada lokasi tersebut diambil sampel air, sedimen, dan kerang hijau. Pengambilan sampel air dilakukan secara langsung dengan menggunakan botol polietilen (Hutagalung et al., 1997). Pengambilan sampel sedimen menggunakan sedimen grabh (Hutagalung et al, 1997). Pengambilan kerang hijau di perairan dengan bantuan nelayan setempat dan sesuai intruksi dari peneliti. Sampel air, sedimen dan jaringan lunak kerang hijau dibawa ke laboratorium Balai Besar Teknolgi Pencegahan Pencemaran Industri Kota Semarang untuk di analisis kandungan logam berat $\mathrm{Pb}$ menggunakan metode digesti asam dengan menggunakan AAS (Atomic Absorbtion Spectrophotometry) (APHA, 1992).

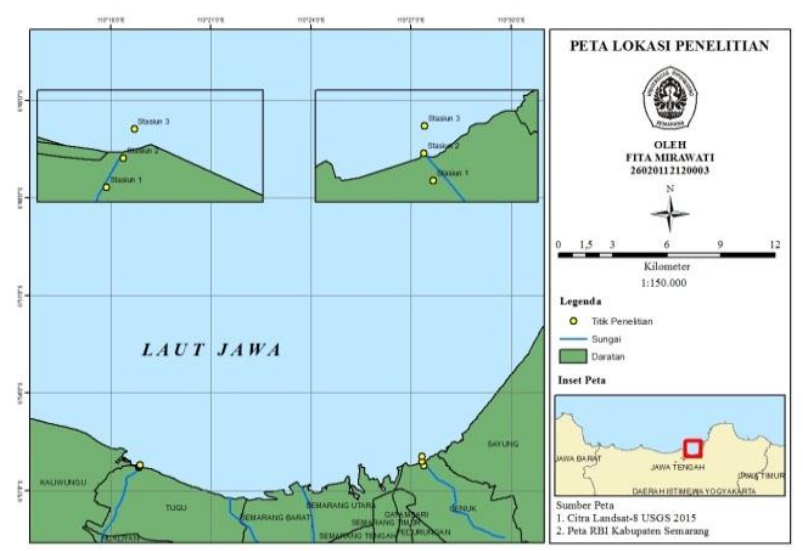

Gambar 1. Peta Lokasi Penelitian

Batas maksimum konsentrasi dari bahan pangan yang terkontaminasi logam berat per minggu (Maximum Weekly Intake) menggunakan angka ambang batas yang diterbitkan oleh organisasi dan lembaga pangan internasional World Health Organization (WHO) dan Joint FAO/WHO Expert Committee on Food Additive (JEFCA). Perhitungan maximum weekly intake menggunakan rumus:

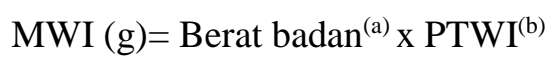

Keterangan:

a) Untuk asumsi berat badan $60 \mathrm{~kg}$

b) PTWI (angka toleransi batas maksimum perminggu) untuk $\mathrm{Pb} \quad 25 \quad \mu \mathrm{g} \cdot \mathrm{kg}^{-1}$ (FAO/WHO,2004).

Setelah mengetahui nilai MWI dan mengetahui konsentrasi logam berat pada biota uji, maka dapat dihitung berat maksimal dalam mengkonsumsi kerang dalam setiap minggunya. Nilai Maximum Tolerable Intake (MTI) dihitung dengan rumus (Turkemen et al., 2008 dalam Mrajita, 2010):

$$
\mathrm{MTI}=\mathrm{MWI} / \mathrm{Ct}
$$


Keterangan:

MWI : Maximum Weekly Intake (g untuk orang dengan berat badan $60 \mathrm{~kg}$ per minggu)

$\mathrm{Ct}$ : Konsentrasi logam berat yang ditemukan di dalam jaringan lunak $(\mathrm{g} / \mathrm{kg})$

\section{HASIL DAN PEMBAHASAN}

\section{Kandungan Logam Berat Pb}

Hasil pengukuran logam berat $\mathrm{Pb}$ pada air, sedimen dan kerang hijau (P. viridis) diperairan Trimulyo dan Mangunharjo Semarang disajikan dalam Tabel 1. Hasil analisis kandungan logam berat $\mathrm{Pb}$ pada air di perairan Trimulyo dan Mangunharjo Semarang $<0,003 \mathrm{mg} / \mathrm{l}$. Kandungan logam berat $\mathrm{Pb}$ pada sedimen stasiun 1 dan 2 dikedua lokasi $<0,030 \mathrm{mg} / \mathrm{kg}$, sedangkan pada stasiun 3 di lokasi Trimulyo 5,96 mg/kg dan 3,69 $\mathrm{mg} / \mathrm{kg}$ untuk lokasi Mangunharjo. Kandungan logam berat $\mathrm{Pb}$ pada kerang hijau (P. viridis) di lokasi Trimulyo dan Mangunharjo pada stasiun 2 sebesar $0,26 \mathrm{mg} / \mathrm{kg}$ dan $0,19 \mathrm{mg} / \mathrm{kg}$. pada stasiun 3 sebesar $0,32 \mathrm{mg} / \mathrm{kg}$ dan $0,39 \mathrm{mg} / \mathrm{kg}$. sedangkan pada satasiun 1 dikedua lokasi tidak ditemukan kerang hijau sehingga tidak bisa dilakukan analisis kandungan logam beratnya (Gambar 2 dan 3).

Kandungan logam berat $\mathrm{Pb}$ pada air dikedua lokasi $<0,003 \mathrm{mg} / \mathrm{l}$. nilai tersebut masih dibawah ambang batas baku mutu yang ditentukan oleh KMNLH No.51 tahun 2004 yaitu $0,008 \mathrm{mg} / \mathrm{l}$. Logam berat masuk ke perairan dipengaruhi oleh faktor fisika, kimia, maupun biologi (Mandelli, 1976). Selain itu Cepat lambatnya arus akan mempengaruhi laju persebaran logam berat di perairan. Arus yang kuat cenderung logam beratnya rendah, hal ini karena logam berat akan cepat terdistribusi merata (Mukhtasor, 2007). Pada kedua lokasi memiliki arus yang sangat kuat pada stasiun $1(0,13 \mathrm{~m} / \mathrm{s}$ dan $0,15 \mathrm{~m} / \mathrm{s})$, kemudian stasiun $2(0,10 \mathrm{~m} / \mathrm{s}$ dan $0,13 \mathrm{~m} / \mathrm{s})$ dan stasiun $3(0,05 \mathrm{~m} / \mathrm{s}$ dan $0,08 \mathrm{~m} / \mathrm{s})$ diduga kandungan logam berat yang ada pada hulu sungai terbawa oleh arus yang kuat menuju ke laut lepas dan terdistribusi merata sehingga kandungan logam berat pada air terdeteksi sangat kecil.

Kandungan logam berat pada sedimen stasiun 1 dan 2 di kedua lokasi rata-rata $<0,030$ $\mathrm{mg} / \mathrm{kg}$. sedangkan pada stasiun 3 sebesar 5,96 $\mathrm{mg} / \mathrm{kg}$ dan 3,69 mg/kg. hasil kandungan logam berat pada stasiun 3 lebih tinggi dibanding stasiun lainnya disebabkan karena pengadukan oleh arus yang kuat. Diduga pada stasiun 1 dan 2 terjadi pengadukan oleh arus yang kuat dan terendapkan pada stasiun 3 yang memiliki arus lebih lemah. Selain itu diduga pada stasiun 3 memiliki masukan polutan yang mengandung logam berat $\mathrm{Pb}$ dari aktivitas Pelabuhan Tanjung Mas maupun aktivitas nelayan pencari ikan dilaut yang menggunakan bahan bakar mengandung logam timbal dan terendapkan didasar perairan sehingga ion logam berat $\mathrm{Pb}$ berikatan dengan sedimen di dasar perairan (Begum, 2009).

Kandungan logam berat $\mathrm{Pb}$ pada kerang hijau (P. viridis) di lokasi Trimulyo pada stasiun 2 dan 3 rata-rata $0,26 \mathrm{mg} / \mathrm{kg}$ dan $0,32 \mathrm{mg} / \mathrm{kg}$, sedangkan pada lokasi Mangunharjo pada stasiun 2 rata-rata $0,19 \mathrm{mg} / \mathrm{kg}$ dan $0,39 \mathrm{mg} / \mathrm{kg}$ pada stasiun 3. Pada kedua lokasi di stasiun 1 tidak ditemukan kerang hijau sehingga tidak bisa dilakukan analisis kandungan logam berat $\mathrm{Pb}$. Hal tersebut dikarenakan stasiun 1 merupakan daerah pemukiman $(500 \mathrm{~m}$ sebelum muara) tidak ditemukan tempat untuk kerang hijau menempel dan berkembang biak. Sesuai dengan cara hidup kerang hijau yaitu menempel pada substrat yang keras seperti kayu, bambu, bangunan pantai, dan media keras lainnya (Kastoro, 1988). Kontaminasi zat beracun pada organisme melalui permukaan organisme, respirasi, dan pengambilan makanan yang mengandung bahan pencemar (Jardin, 1993). Logam berat $\mathrm{Pb}$ yang diabsorbsi dari perairan ke badan organisme melewati sejumlah membrane sel yang terdiri dari lapisan biomolekuler yang dibentuk oleh molekul lipid dengan molekul protein yang tersebar diseluruh membarane. Setelah didalam sel logam akan membentuk ikatan kompleks dengan ligan. Logam berat dan berikatan dengan gugus sulfihidril, hidroksil, karboksil, imidazole, dan amino dari protein, ion logam berat paling efektif berikatan dengan gugus sulfihidril (-SH). Mekanisme kerja reaksi dari logam terhadap protein, pada umumnya menyerang ikatan sulfide. Penyerangan ikatan sulfide yang selalu ada pada molekul protein menimbulkan kerusakan protein terkait, sehingga menyebabkan daya kerjanya berkurang atau bahkan sama sekali tidak bekerja, keadaan tersebut secara keseluruhan akan merusak metabolisme tubuh (Palar, 2004). Logam berat $\mathrm{Pb}$ akan menerus terakumulasi dalam tubuh biota, sehingga apabila manusia mengkonsumsi biota dari perairan yang tercemar akan menimbulkan berbagai penyakit seperti pusing, mual, dan kanker (Palar, 2004).

\section{Konsumsi Maksimum Mingguan}

Berat maksimum jaringan lunak kerang hijau (P. viridis) yang dikonsumsi tiap minggu 
Tabel 1. Hasil Rata-rata Kandungan Logam Berat Pb pada Air, Sedimen, dan Kerang Hijau (P. viridis) di Perairan Trimulyo dan Mangunharjo Semarang

\begin{tabular}{cccccccc}
\hline \multirow{2}{*}{ Parameter } & \multicolumn{3}{c}{ Trimulyo } & \multicolumn{3}{c}{ Mangunharjo } & Baku \\
\cline { 2 - 7 } & St.1 & St.2 & St.3 & St.1 & St.2 & St.3 & Mutu \\
\hline Air $(\mathrm{mg} / \mathrm{l})$ & $<0,003$ & $<0,003$ & $<0,003$ & $<0,003$ & $<0,003$ & $<0,003$ & $0,008^{\text {a) }}$ \\
Sedimen $(\mathrm{mg} / \mathrm{kg})$ & $<0,030$ & $<0,030$ & 5,96 & $<0,030$ & $<0,030$ & 3,69 & $36^{\text {b) }}$ \\
Kerang $(\mathrm{mg} / \mathrm{kg})$ & - & 0,26 & 0,32 & - & 0,19 & 0,39 & $1,5^{\text {c) }}$ \\
\hline
\end{tabular}

Keterangan:

a) Baku mutu air laut menurut Keputusan Menteri Lingkungan Hidup No.51 tahun 2004

b) Baku mutu sedimen dengan standar sediment quality guideline values for metals and associated levels of concern to be used in doing assessments of sediment quality tahun 2003

${ }^{c}$ Batas maksimum cemaran logam berat oleh Badan Standarisasi Nasional tahun 2009

-)Tidak ditemukan Kerang Hijau (P. viridis)

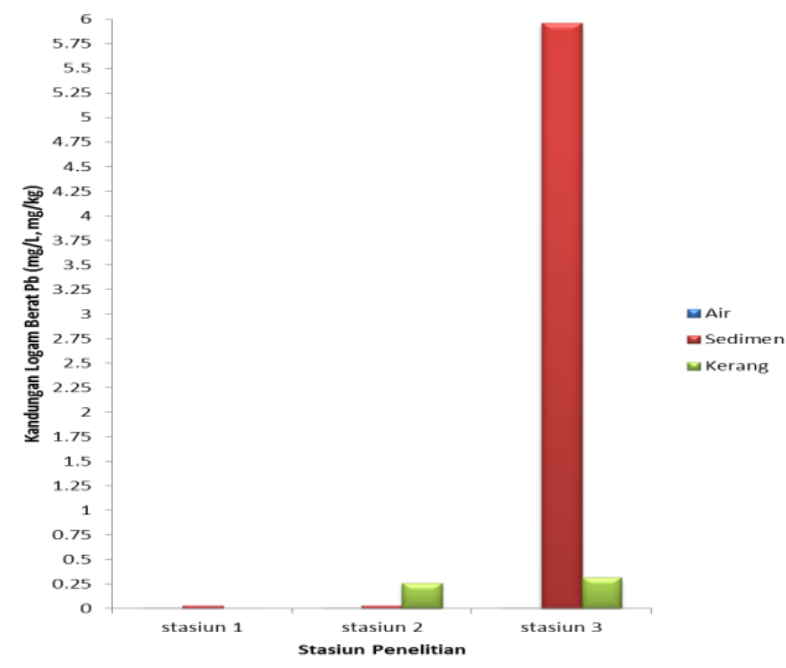

Gambar 2. Kandungan logam berat $\mathrm{Pb}$ pada air, sedimen, dan P. viridis di Perairan Trimulyo

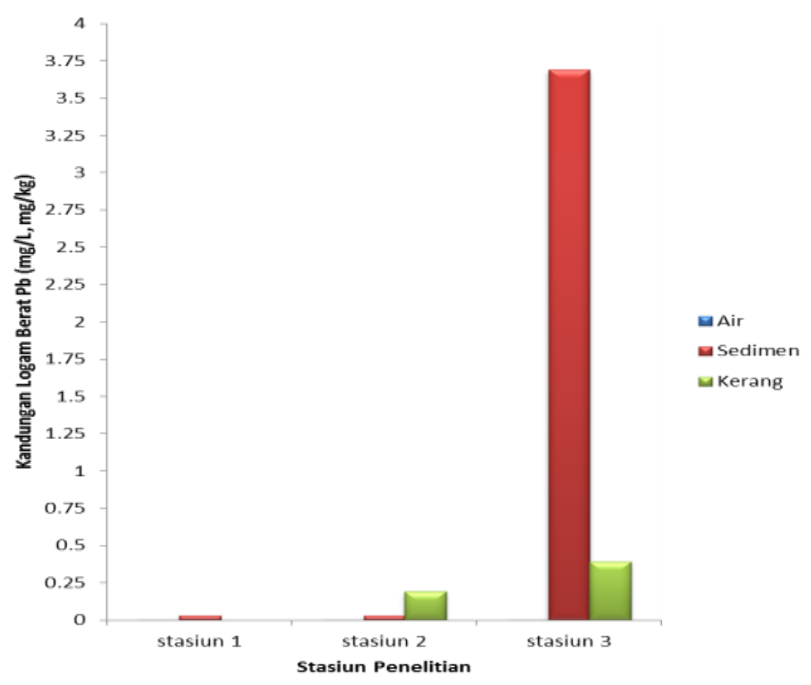

Gambar 3. Kandungan logam berat $\mathrm{Pb}$ pada air, sedimen, dan P. viridis di Perairan Mangunharjo 
menurut rumus Turkemen et al. (2008) disajikan pada Tabel 2 dan 3. Nilai MWI (Maximum Weekly Intake) logam $\mathrm{Pb}$ yang dapat dikonsumsi menurut WHO (1982) adalah $1,5 \mathrm{mg}$ perminggu yang didapat dari PTWI (logam berat Pb 0,025 mg/kg) dikalikan dengan berat badan. Nilai MTI (Maximum Tolerable Intake) didapat dari nilai MWI dikalikan dengan konsentrasi kandungan logam berat pada kerang yang diuji dengan AAS sebelumnya. Nilai MTI pada individu dewasa dengan berat badan $60 \mathrm{~kg}$ di perairan Trimulyo dan Mangunharjo pada stasiun 2 masing-masing $5,769 \mathrm{~kg}$ dan $7,895 \mathrm{~kg}$. pada stasiun 3 sebesar $4,688 \mathrm{~kg}$ dan $3,846 \mathrm{~kg}$. sebagai perbandingan maka dihitung untuk individu dewasa dengan berat badan $45 \mathrm{~kg}$ di lokasi Trimulyo dan Mangunharjo pada stasiun 2 masing-masing 4,327 $\mathrm{kg}$ dan $5,921 \mathrm{~kg}$ pada stasiun 3 sebesar $3,516 \mathrm{~kg}$ dan 2,885 kg pada stasiun 1 dikedua lokasi tidak bisa dihitung nilai MTI dikarenakan tidak ditemukannya kerang pada stasiun ini.

Tabel 2. Berat Maksimal Asupan Logam Berat yang Aman Dikonsumsi Per Minggu (Individu Berat Badan rata-rata 60kg)

\begin{tabular}{|c|c|c|c|c|}
\hline \multirow[t]{2}{*}{$\mathrm{St}$} & \multicolumn{2}{|c|}{$\begin{array}{l}\text { Nilai MTI } \\
(\mathrm{Kg})\end{array}$} & \multirow[t]{2}{*}{$\begin{array}{c}\text { PTWI } \\
(\mathrm{mg} / \mathrm{kg})\end{array}$} & \multirow[t]{2}{*}{$\begin{array}{l}\text { MWI } \\
(\mathrm{mg})\end{array}$} \\
\hline & Tri & $\mathrm{Mn}$ & & \\
\hline 1 & - & - & 0,025 & 1,5 \\
\hline 2 & 5,769 & 7,895 & 0,025 & 1,5 \\
\hline 3 & 4,688 & 3,846 & 0,025 & 1,5 \\
\hline
\end{tabular}

Tabel 3. Berat Maksimal Asupan Logam Berat yang Aman Dikonsumsi Per Minggu (Individu Berat Badan rata-rata 45kg)

\begin{tabular}{ccccc}
\hline St & \multicolumn{2}{c}{$\begin{array}{c}\text { Nilai MTI } \\
(\mathrm{Kg})\end{array}$} & \multirow{2}{*}{$\begin{array}{c}\text { PTWI } \\
(\mathrm{mg} / \mathrm{kg})\end{array}$} & $\begin{array}{c}\text { MWI } \\
(\mathrm{mg})\end{array}$ \\
\cline { 2 - 3 } & Tri & Mn & & \\
\hline 1 & - & - & 0,025 & 1,125 \\
2 & 4,327 & 5,921 & 0,025 & 1,125 \\
3 & 3,516 & 2,885 & 0,025 & 1,125 \\
\hline
\end{tabular}

Nilai MTI tersebut digunakan sebagai acuan batas konsumsi mingguan kerang hijau yang didapat dari lokasi Trimulyo dan Mangunharjo Semarang, apabila individu yang memiliki berat badan rata-rata $60 \mathrm{~kg}$ dan $45 \mathrm{~kg}$ mengkonsumsi kerang hijau melebihi nilai MTI maka logam berat $\mathrm{Pb}$ bisa bersifat toksik bagi manusia. Keracunan akut $\mathrm{Pb}$ dapat menyebabkan gangguan fungsi pada otak, disfungsi hati maupun ginjal dan gangguan reproduksi (Murakami et al., 1993). Ditambahkan lagi bahwa dosis yang menyebabkan lethal (kematian) manusia diperkirakan terjadi jika $500 \mathrm{mg}$ atau $0,5 \mathrm{~g} \mathrm{~Pb}$ terserap kedalam tubuh (Rahde, 1991).

\section{KESIMPULAN}

Kandungan logam berat $\mathrm{Pb}$ dalam air di Perairan Trimulyo dan Mangunharjo Semarang rata-rata sebesar $<0,003 \mathrm{mg} / \mathrm{l}$, dalam sedimen diPerairan Trimulyo berkisar antara $<0,030-5,96$ $\mathrm{mg} / \mathrm{kg}$, dan di Perairan Mangunharjo berkisar antara $<0,030-3,69 \mathrm{mg} / \mathrm{l}$. Sedangkan kandungan logam berat $\mathrm{Pb}$ dalam jaringan lunak kerang hijau (Perna viridis) di Perairan Trimulyo berkisar antara 0,26-0,32 $\mathrm{mg} / \mathrm{kg}$ dan di Perairan Mangunharjo berkisar antara $0,19-0,39 \mathrm{mg} / \mathrm{kg}$. Tingkat pencemaran logam berat $\mathrm{Pb}$ dalam air, sedimen, dan kerang hijau (Perna viridis) di Perairan Trimulyo dan Mangunharjo Semarang masih berada dibawah ambang batas baku mutu yang telah ditentukan oleh Keputusan Menteri Lingkungan Hidup No.51 tahun 2004. Berat maksimal asupan kerang hijau yang aman dikonsumsi perminggu pada Perairan Trimulyo dan Mangunharjo Semarang untuk individu dengan berat badan $60 \mathrm{~kg}$ yaitu $5,769 \mathrm{~kg} / \mathrm{minggu}$ dan $7,895 \mathrm{~kg} / \mathrm{minggu}$. sedangkan untuk individu dengan berat badan $45 \mathrm{~kg}$ yaitu $4,327 \mathrm{~kg} /$ minggu dan $5,921 \mathrm{~kg} /$ minggu.

\section{UCAPAN TERIMAKASIH}

Penulis menyampaikan terimaksih kepada semua pihak yang membantu dalam penelitian dan penyusunan artikel ini.

\section{DAFTAR PUSTAKA}

APHA. 1992. Standart Method for The Examination of Water and Wastewater. $18^{\text {th }}$ edition. Washington, 2552p.

Begum, A., Romaiah M., Harkrishna,S., Khan, I. \& Veena, K. 2009. Heavy Metal Pollution and Chemical Profile of Cauvery River Water. J. Chem. 6(1):47-52

Bogdan, R.C \& Bieklen, S.K. 1982. Qualitative Research for Education: An Introduction to Theory and Methods, Boston: Allyn and Bacon, Inc.

Fardiaz. 2002. Polusi Air dan Udara. Kanisius. Yogyakarta.23-25 hlm.

FAO/WHO. 2004. Summary of Evaluations Performed by The Joint FAO/WHO Expert Committee on Food Additives (JECFA 19562003) ILSI Press International Life Science Institute, Washington.

Hadi, S. 1990. Metodologi Research. Penulis Paper, Skripsi, Thesis dan Disertasi. Yayasan 
Penerbit Fakultas Psikologi UGM, Yogyakarta, $75 \mathrm{hlm}$.

Hutagalung, D. Setiapermana, \& S.H. Riyono. 1997. Metode Analisa Air Laut, Sedimen, dan Biota. Buku 2. P3O-LIPI, Jakarta, 182 hlm.

Jardin, C.G.1993. Effect of Pollutan at The Ecosystem Level. Enviromental Toxicology Seminar. Diponegoro University Semarang Central Java. 15 hlm.

Kastoro, W. 1988. Beberapa Aspek Biologi Kerang Hijau (Perna viridis) dari Perairan Binaria, Ancol Teluk Jakarta. J. Perikanan Laut. 45:83-102.

Mandelli, E.1976. Monitoring of trace elements other than radio-nuclides. Dalam "Manual of methods in aquatic environment research". FAO Fisheries technical paper. 150(I2):2737.

Mrajita, C.V.P. 2010. Kandungan Logam Berat pada Beberapa Biota Kekerangan di
Kawasan Littoral Pulau Adonara (Kabupaten Flores Timur, Nusa Tenggara Timur) dan Aplikasinya dalam Analisis Keamanan Kunsumsi Publik. [Thesis]. Program Magiter Manajemen Sumberdaya Pantai Universitas Diponegoro Semarang.

Mukhtasor. 2007. Pencemaran Pesisir dan laut,Penerbit PT. Pradnya Paramitha, Jakarta. $332 \mathrm{hlm}$.

Murakami, K., Feng, G. \& Chen, S.G. 1993. Inhibion of Brain Kinase Subtypes by Lead. J. Pharmacol. Exp. Ther., 264(2):757-761.

Palar, H. 1994. Pencemaran dan Toksikologi Logam Berat. PT. Rineka Cipta, Jakarta. 152 hlm.

2004. Pencemaran dan Toksikologi Logam Berat, Penerbit : PT.Rineka Cipta, Jakarta.

Rahde, A.F. 1991. Lead Inorganic. IPCS INCHEM, pp. 1-24. 